\title{
PSYCHE
}

VOL. XXXVII

\section{ANT-TREE NOTES FROM RIO FRIO, COLOMBIA}

By W. M. Wheeler ANd P. J. Darlington, JR.

The observations recorded in the following pages on the various insects inhabiting Triplaris, Cecropia and Acacia trees in the vicinity of Rio Frio, Colombia, were made by the junior author during 1928-'29. The only contribution of the senior author is the identification of the ants which regularly inhabit the trunks and twigs of Triplaris and Cecropia and the large thorns of Acacia, and some data secured in 1927-'28 in the same locality by Dr. George Salt. It has been impossible to obtain accurate specific identifications of the plants, because they were not in bloom when the observations were made.

\section{TRIPLARIS AND ITS INHABITANTS}

Two forms of this tree were found, one (Plate 1, lower fig.) with narrow, lanceolate leaves and apparently the same as the T. americana Linné which has been studied by the senior author in Panama, the other (Plate 1, upper fig.) with broader, more ovate leaves and perhaps merely a variety of the preceding. The narrow-leaved form is a small, straight, slender tree somewhat resembling a hickory in general appearance. Near Rio Frio it is rather closely restricted to the edges of brooks in and near the foot-hills of the Sierra Nevada de Santa Marta. It usually grows so close to the brook that it can get water during the dry season, for it is one of the few trees of the lower foothills which is not deciduous. No specimens of it were seen above 1500 feet. 
When the narrow-leaved Triplaris is inhabited by Pseudomyrma triplarina, it ranks with the terrible nettle (Jatropha urens L.) that grows in much the same sort of place. Both plants offer tempting holds on the steep slopes along the brooks, and a few stings from either the nettle or the ants will cause the hands to swell painfully. Ants and their brood occupy cavities in the central stem and its lateral branches throughout the Triplaris, except near the base of the larger trees. The cavities, which are continuous and are apparently cut through the nodes by the ants, may be occupied up to the last or next to the last internode below the terminal bud. The entrances are perpendicular slits in the stem or branches and are about $120^{\circ}$ around the stem from the base of the leaf next above. They are usually just below a node, but may be more than half way down to the node below. There is almost always at least one entrance to a node, and there may be several, one above the other.

In very young stems the medullary cavity is about half the diameter of the stem, nearly round in cross-section, except for the depressions noted below, and somewhat enlarged between the nodes. The passage through each node is greatly constricted. In stems an inch and a half in diameter the entrance may remain open, but the cavity even in the oldest stems is scarcely or not at all larger than in young twigs. The walls of the cavities in the latter are brown; in old twigs, black.

The depressions mentioned above are vertical, slit-like grooves in the walls of the cavities and are of two kinds, those which open into entrances and those which extend only to the inner surface of the bark and are used to house Coccids. The position of the entrances has been described; the Coccid houses have a rather more irregular location, but often seem to be incompleted entrances, to which in many cases they correspond in position. They are frequently placed just below leaf attachments, however, where there is often a smooth, slightly depressed area on the external surface of the bark. Whether these "Coccid houses" are natural or cut by the ants was not ascertained.

The Colombian Triplaris and its ants had been previously observed by Forel, and Dr. Salt. We quote the latter's 
notes of October 16, 1927: "Quebrada Rodriguez, Rio Frio. A small tree of Triplaris sp. (americana ? according to Johansen) about 12-15 feet high and 2 inches at 5 feet above the ground, was felled and some of the ants collected. They sting viciously, the poison causing the fingers to swell and bringing out red flushes right up to the arm. The ant-brood and coccids were found in the branches and at the tip. In every case the coccids were found at the upper or distal end of the internode, frequently right up against the partition, and the ant-brood at the lower or proximal end. In several places on the inside of the hollow trunk the wood was deeply pitted but not perforated. It was not determined whether the pits were made by the ants or were normal depressions. The exit holes of the ants are regular in position and undoubtedly are merely modifications of some previously existing structures (lenticels?) of the plant."

The following insects were found by the junior author associated with the narrow-leaved Triplaris (Plate 1., Iower fig.) :

1. Pseudomyrma triplarina Weddel subsp. symbiotica Forel. Probably the commonest and certainly the most vicious ant in the Triplaris. It does not inhabit every tree, however, nor does it always take complete possession, for it was sometimes found sharing trees with No. 3. Series of this ant were also taken by Dr. Salt in Triplaris, presumably of the narrow-leaved form, at Rio Frio and Aracataca.

2. Azteca theresiæ Forel. A common species forming large colonies. It bites but does not sting and was found sharing trees with Nos. 1 and 3. The var. menceps Forel of this species is a very common tenant of T. americana in Panama, according to the senior author's observations.

3. Crematogaster (Orthocrema) parabiotica Forel. A small, inoffensive ant which often colonizes single branches of trees inhabited by one or both of the preceding species.

Apparently these three ants are all capable of maintaining their colonies without leaving the home tree. At any 
rate, this is true of the Pseudomyrma, for two of the Triplares were banded with tanglefoot and their foliage thus isolated on December 17, 1928. One tree was about four inches through at the base and twenty feet tall; the other about five-eighths of an inch by nine feet. At the time both were inhabited by pure Pseudomyrma colonies, which remained reasonably healthy till the middle of February, when the experiment was discontinued. The larger tree, however, may have lost a part of its Pseudomyrma population (this point was, of course, very difficult to determine) and certainly acquired a small colony of Crematogaster in the interval. Only one or two ants were caught in the tanglefoot and none was ever seen to attempt to reach the ground. The ants do not maintain a cleared area about the tree.

4. Camponotus (Myrmocladocus) bidens Mayr. A few specimens of this small, timid ant were taken on a Triplaris with Crematogaster in March. C. bidens and its congeners are known to nest in hollow, dead twigs of a variety of trees.

5. Trachysomus thomsoni Auriv. (det. Fisher). This big cerambycid beetle fells the living Triplaris by gnawing a girdle around the bark and wood of the trunk. It attacks trees up to nearly three inches in diameter. The larvæ feed in the wood of the pruned trunks. Three adults, which were bred out, emerged in July and August, but the precise time of pruning was not ascertained.

Trees that have been killed attract a number of woodboring Coleoptera, which are listed below. The order of their appearance was determined from a tree which was felled with a machete on December 17.

6. Steirastoma stellio Pasc. (det. Fisher). This is a cerambycid which was seen only during the first week after felling. Seven specimens were taken, all clinging to the lower side of the felled trunk, so the species is probably nocturnal.

7. Odontocera sp. nov. (being described by Fisher). This cerambycid, of the tribe Necydalini, appeared during 
the first week after felling and continued to come for nearly a month. It bred abundantly in the Triplaris. The beetles are diurnal and may be seen hovering and dipping over the dead wood like Vespidæ. There is one vespid which they very much resemble and which sometimes occurs with them. The beetles were caught or bred out in January, March, May, June, July and December, so the species is probably multiple-brooded. Four specimens were taken in June near Santa Marta, on wood which was not Triplaris, but they may not have been breeding in it.

The two following species behave like this undescribed Odontocera, to which they are closely related. They were so scarce by comparison, however, that they furnished only scanty data.

8. Odontocera fasciata Ol. (det. Fisher). Eleven specimens were taken in January, May and December. Some were breeding with No. 7, some flying to dead Triplaris.

9. Odontocera sp. nov. (being described by Fisher). Five specimens were cut from dead Triplaris with No. 7 in May.

10. Amphicerus cornutus Pallas (det. Fisher). This large bostrychid beetle appeared on the dead Triplaris January 15, about a month after felling. The first specimens were cut from tunnels which entered the hard wood of the trunk at right angles, but curved around parallel to the grain at a depth of about half an inch. On February 17, two months after the tree was felled, five of these beetles were cut from the ramifications of a single tunnel system. The tunnels were, of course, made entirely by the adults and no sign of eggs or larvæ could be found. Two specimens were taken at Santa Marta in May, probably at light.

11. Dendrobiella sericans Lec. (det. Fisher). This small bostrychid was first noticed during the third week after the Triplaris was felled, when adults were boring into the dead trunk. The species was common.

12. Scalidia sp. (det. Fisher). This cucujid appeared with the small bostrychid (No. 11), on which it probably 
preys. At any rate on January 11 one of the cucujids was seen trying to pull a bostrychid out of its gallery entrance by the declivity of the elytra.

13. Chrysobothris viridiimpressa C. \& G. (det. Fisher). One specimen of this buprestid was taken in tanglefoot on a living Triplaris early in January. Two or three other individuals were seen, all on plants of other species, so the occurrence of the beetle on the ant-tree was probably accidental.

14. Membracid, sp. A small, simple species with spotted wings, of which both adult and immature individuals were collected at leaf axils on the Triplaris. The tree was inhabited partly by Azteca and partly by Crematogaster. Neither ant seemed to be paying any attention to the hoppers, however.

15. Pseudococcus probrevipes Morrison. These Coccids live with both the Pseudomyrma and the Azteca. They are usually found in the groove-like channels or pits which are mentioned on page 108, but they may occur at the sides of entrances or around the nodes, always, of course, inside the tree. They are often so crowded into their "houses" that, if feeding is possible only on the inner surface of the bark, they must take turns at it.

The broad-leaved Triplaris (Plate 1, upper fig.) is a smaller, more compact tree than the narrow-leaved form and grows in a different habitat, at the boundary of forest and new clearing far from water. It may perhaps be the same species modified by unfavorable conditions. The wood structure was not examined in detail but seemed to be the same as in the narrow-leaved form. The only ant taken in the broad-leaved Triplaris was Pseudomyrma triplarina symbiotica, but it is comparatively scarce and colonizes only a small proportion of the available plants. The following insects inhabit the twigs or live on the foliage:

16. Thyridid, sp. The greenish larvæ of this moth were found on April 7 in the medullary cavities of Triplaris which had not been colonized by ants. The same or a very 


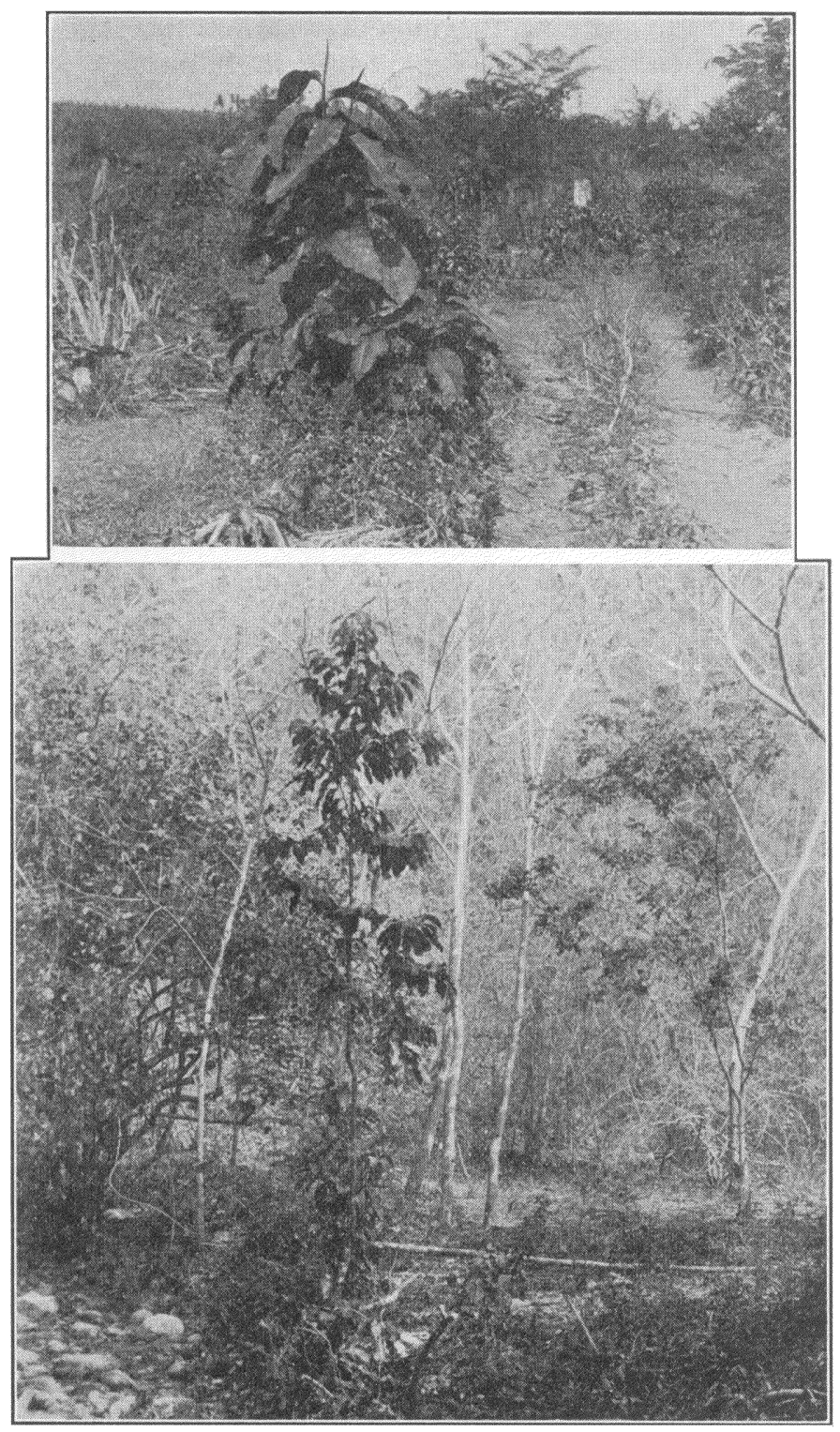

Plate 6

Wheeler and Darlington-Ant-Tree Notes 
similar larva has been frequently taken by the senior author in the twigs of $T$. americana in Panama.

17. Cassidid, sp. This beetle was brilliant green in life. It was common on Triplaris foliage in May. Other specimens were collected in March and November. When the beetles were taken no ants were visible on any of the trees, but this may have been because the latter were too young to have been colonized, or more probably because the colonies produced in the internodes by the recently fecundated females were still undeveloped.

18. Coccids undetermined. Although these may have been present in the ant-inhabited trees, they were taken only in the cavities which had not been colonized.

\section{CECROPIA AND ITS INHABITANTS.}

Cecropias, called locally "guarumo," are common trees in second-growth land and similar situations from sea-level up to at least 4500 feet. They are absent in the very arid regions, however. As has been noticed by other observers, they are among the first trees to come in when cultivated land is abandoned. Although the ants (Azteca alfari Emery) which inhabit the Cecropia bite severely, the tree is so conspicuous and easily avoided that it does not cause much trouble. The ants seem to get all the necessities of life from their trees. At any rate a well-colonized tree which was isolated by machete work and tanglefoot on December 15 seemed to have its population unreduced at least up to February 27. The peculiar structure of the plant has been so often described that it need not be considered in this place. The following insects were found associated with the Cecropias:

19. Azteca alfari Emery. Practically all the plants, except the very young ones, are inhabited by this ant.

20. Azteca xanthochroa Roger. subsp. salti Wheeler, subsp. nov. The worker minor measures $2.5 \mathrm{~mm}$. and is 
gaster, antennæ and legs deep castaneous brown, the head black, the mandibles and corners of the clypeus red. Pilosity shorter and less abundant, especially on the head. Antennal scapes extending a distance greater than their apical diameter beyond the posterior corners of the head.

The female (deälated) measures 10-12 mm. and has a longer and posteriorly narrower head than any of the more shining than the typical form of the species. Thorax, other forms of xanthochroa, with nearly straight sides, deeper excision of the posterior border and less convex eyes. Thorax and gaster somewhat darker, more reddish yellow; head, antennæ and femora red, clypeus and mandibles deep red. Hairs on the body and tibiæ blackish, long and abundant; appressed pubescence also long but yellowish.

Described from numerous workers and fifteen females, constituting small incipient colonies, taken by Dr. George Salt from the internodes of young Cecropias at Vista Nieve, Sierra Madre de Santa Marta, Colombia, at an altitude of 5000 feet.

21. Coelomera cayennensis Fabr. In life this Chrysomelid beetle has bluish-black elytra and a reddish prothorax. It is very common on young plants, but never, in the experience of the junior author, on the older ones. The old plants often have the leaves stippled with minute holes, the origin of which was not discovered, but never have the marks of beetle feeding. Nor were any of the chrysomelids seen on Cecropias containing developed colonies of Azteca, but this may, of course, have been because the beetles preferred the young plants as food and not because they had been driven away from the older ones by the ants. Beetles were taken in January, February, May, June, July, November and December. They are, therefore, probably either multiple-brooded or always present.

During the rains, probably in May, the junior author feels reasonably certain that he saw large Scarabæids (apparently Pelidnota sp.) feeding on young Cecropias, but he did not know at the time that the plants were worth study. 
22. Coccids. These were found in the cavities of the Cecropias with Azteca.

It is noteworthy that dead Cecropia logs failed to attract borers, although they were carefully examined at different times.

Birds were not seen to visit Triplaris, but the Cecropias were observed to be favorite feeding grounds of several species, particularly in November. Some of the species noted were:

Forpus spengeli (Hartlaub), a minute, green and blue parrot,

Brotogeris jugularis jugularis (Müller), a small green parrot,

Momotus momota subrufescens Sclater, the local motmot,

Pteroglossus torquatus nuchalis Cabanis, a toucan,

Centurus rubricapillus rubricapillus Cabanis, a common woodpecker,

Thraupis episcopus cana (Swainson), a common tanager. None of these birds was ever seen to act as if it had been attacked by the ants.

\section{Note OF ACACIA.}

Ant-inhabited acacias were found only near Aracataca, in the extreme southern part of the region over which the junior author collected. The largest plant examined was hardly more than ten feet high. Though he had no opportunity to study the relations of the ants to the plants in detail, he secured a number of the former from the large thorns. They prove to be specimens of Pseudomyrma spinicola Emery subsp. gaigei Forel. The types of this form were taken by Dr. F. M. Gaige at Fundacion, south of Santa Marta, probably from thorns of the same species of Acacia. The senior author has found a very similar form of Ps. spinicola in the thorns of $A$. penonomensis on the Pacific side of the Panamanian isthmus. The spines of 
the Colombian Acacia secured by the junior author resemble those of the Mexican A. Hernandezi Safford, but the plant is probably undescribed, because no bull-thorn acacias seem to have been recorded from Colombia.

\section{Description of Plate 6}

\section{Above}

Triplaris sp. ("Broad-leaved Triplaris"). A five-foot tree in characteristic habitat near Rio Frio.

\section{Below}

Triplaris sp., probably T. americana Linné ("Narrowleaved Triplaris"). A twenty-five-foot tree in characteristic habitat near Rio Frio. The felled tree upon which wood-boring insects were collected lies across the foreground. 

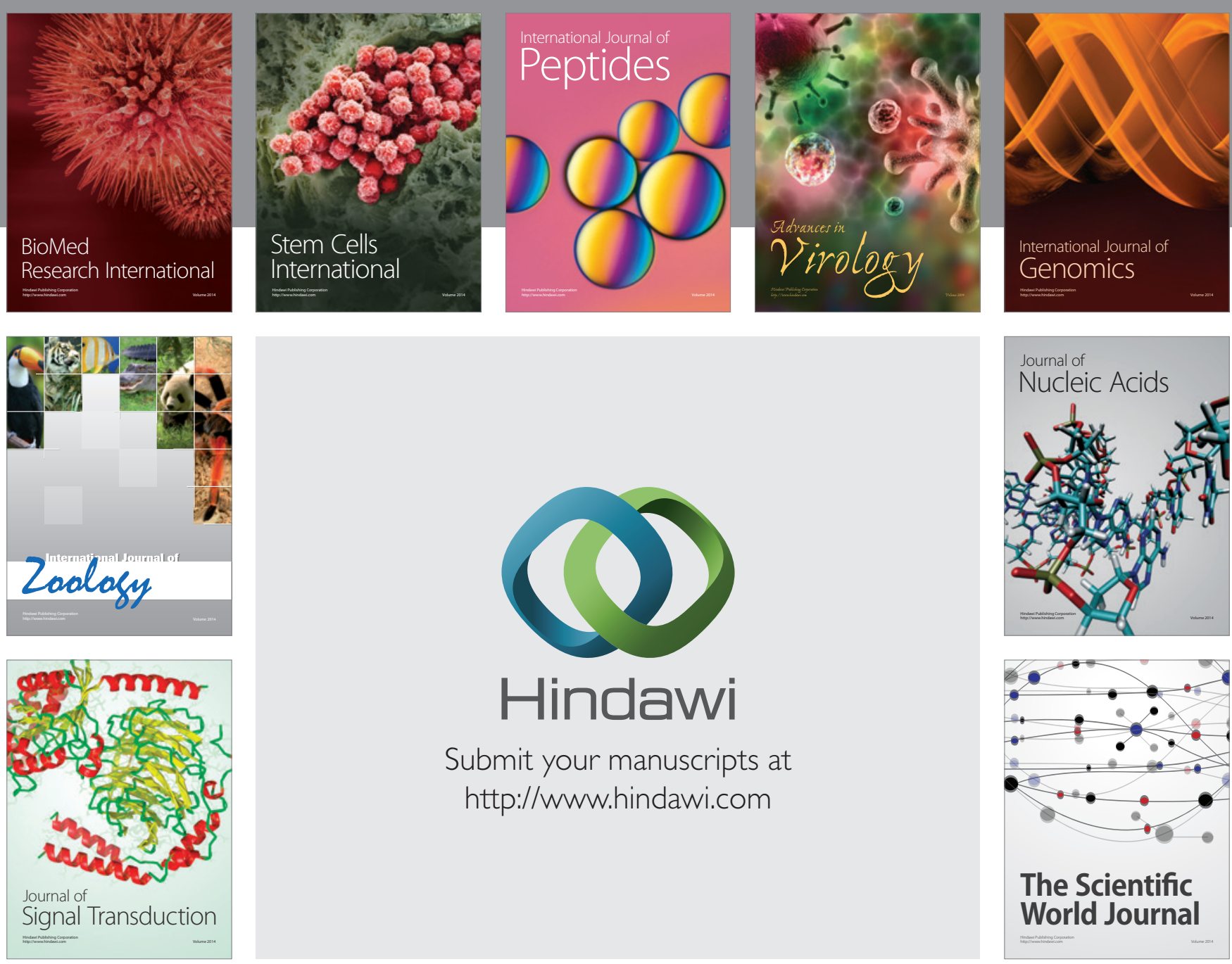

Submit your manuscripts at

http://www.hindawi.com
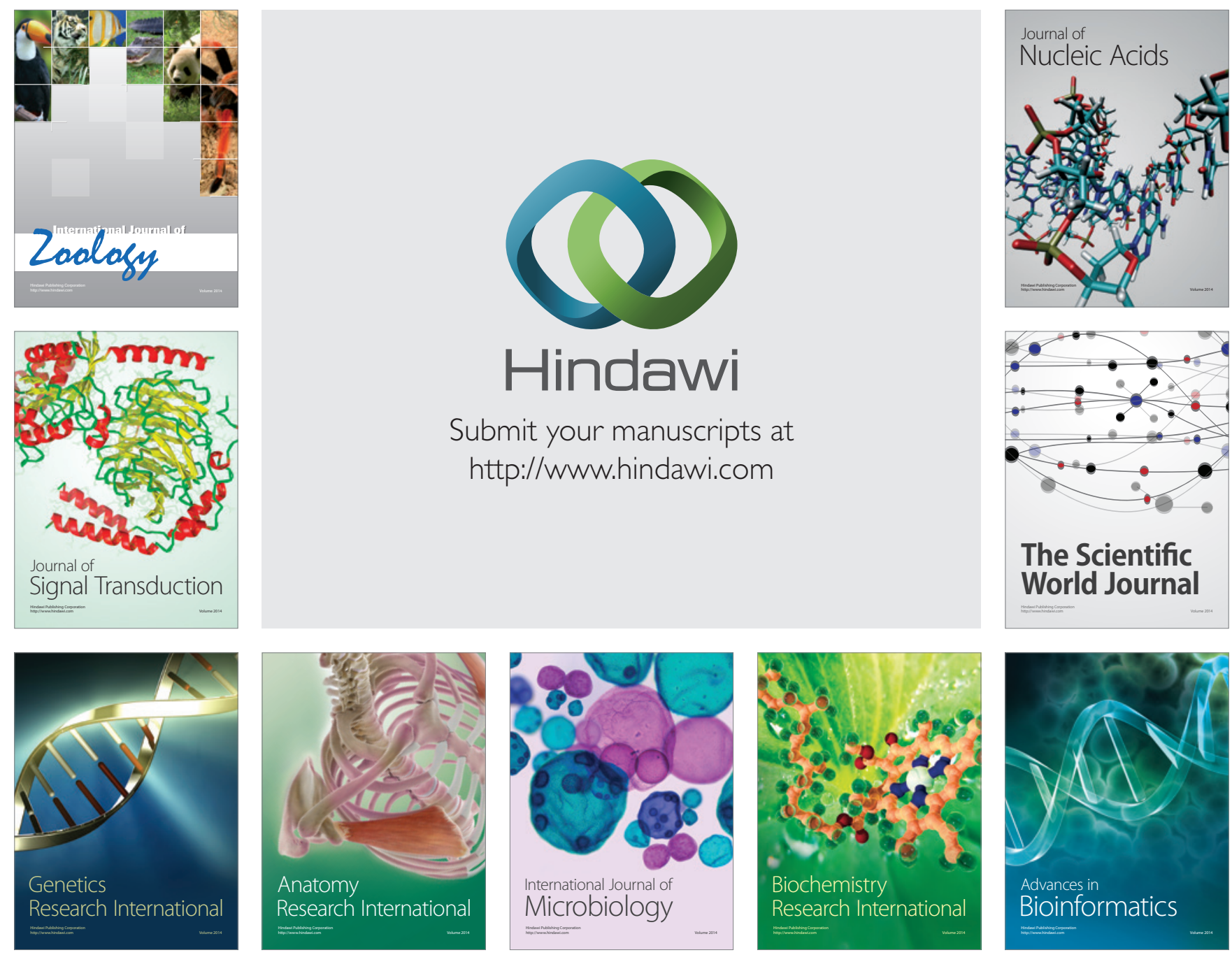

The Scientific World Journal
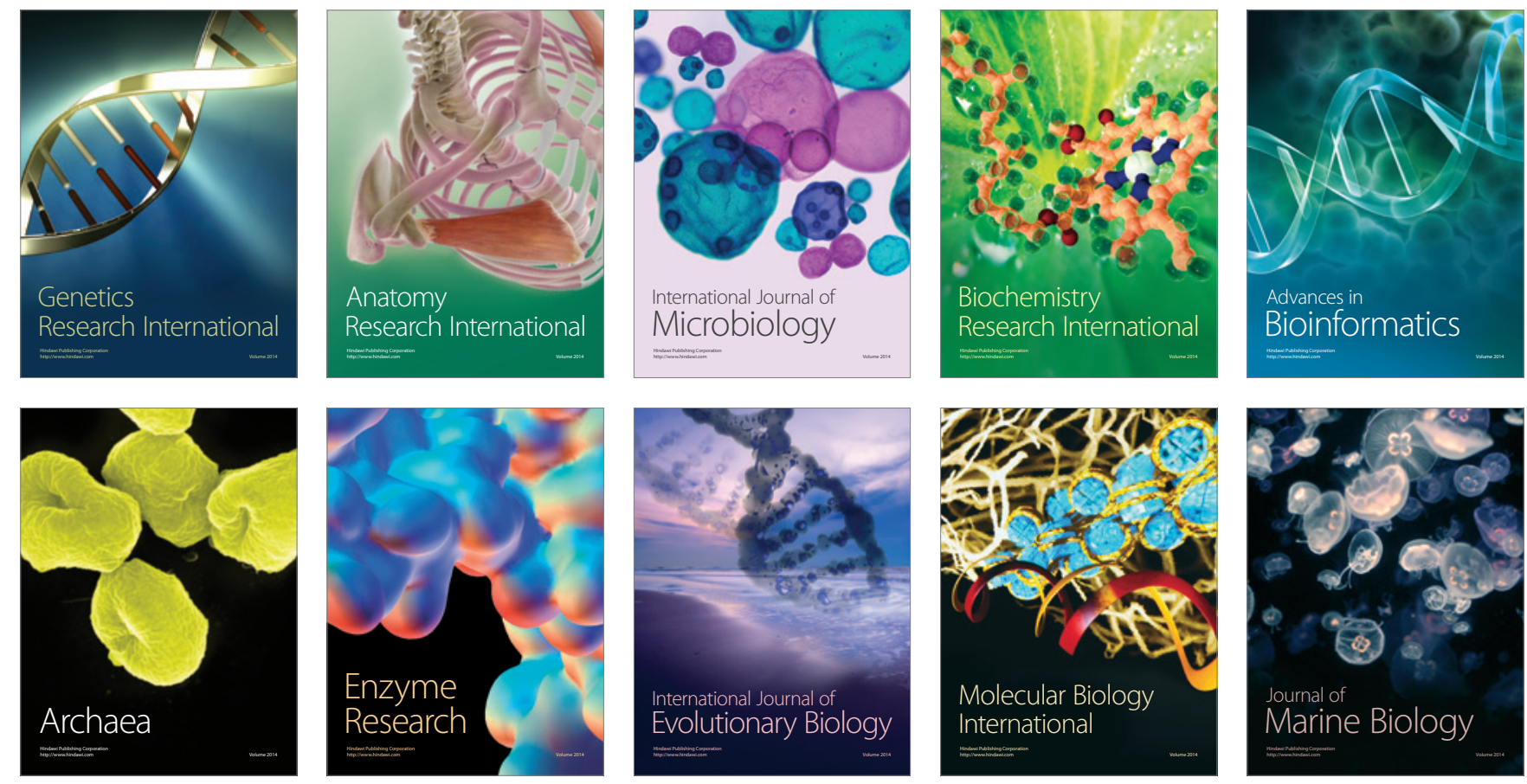